\title{
Intragenic sequences in the trophectoderm harbour the greatest proportion of methylation errors in day 17 bovine conceptuses generated using assisted reproductive technologies
}

\author{
Alan M. O'Doherty ${ }^{1 *}$ (D), Paul McGettigan ${ }^{1}$, Rachelle E. Irwin², David A. Magee ${ }^{1}$, Dominic Gagne ${ }^{3}$, Eric Fournier ${ }^{3}$, \\ Abdullah Al-Naib ${ }^{4}$, Marc-André Sirard ${ }^{3}$, Colum P. Walsh ${ }^{2}$, Claude Robert ${ }^{3}$ and Trudee Fair ${ }^{1}$
}

\begin{abstract}
Background: Assisted reproductive technologies (ART) are widely used to treat fertility issues in humans and for the production of embryos in mammalian livestock. The use of these techniques, however, is not without consequence as they are often associated with inauspicious pre- and postnatal outcomes including premature birth, intrauterine growth restriction and increased incidence of epigenetic disorders in human and large offspring syndrome in cattle. Here, global DNA methylation profiles in the trophectoderm and embryonic discs of in vitro produced (IVP), superovulation-derived (SOV) and unstimulated, synchronised control day 17 bovine conceptuses (herein referred to as Al) were interrogated using the EmbryoGENE DNA Methylation Array (EDMA). Pyrosequencing was used to validate four loci identified as differentially methylated on the array and to assess the differentially methylated regions (DMRs) of six imprinted genes in these conceptuses. The impact of embryo-production induced DNA methylation aberrations was determined using Ingenuity Pathway Analysis, shedding light on the potential functional consequences of these differences.

Results: Of the total number of differentially methylated loci identified (3140) 77.3 and 22.7\% were attributable to SOV and IVP, respectively. Differential methylation was most prominent at intragenic sequences within the trophectoderm of IVP and SOV-derived conceptuses, almost a third (30.8\%) of the differentially methylated loci mapped to intragenic regions. Very few differentially methylated loci were detected in embryonic discs (ED); 0.16 and $4.9 \%$ of the differentially methylated loci were located in the ED of SOV-derived and IVP conceptuses, respectively. The overall effects of SOV and IVP on the direction of methylation changes were associated with increased methylation; $70.6 \%$ of the differentially methylated loci in SOV-derived conceptuses and $57.9 \%$ of the loci in IVP-derived conceptuses were more methylated compared to Al-conceptuses. Ontology analysis of probes associated with intragenic sequences suggests enrichment for terms associated with cancer, cell morphology and growth.

(Continued on next page)
\end{abstract}

\footnotetext{
* Correspondence: alan.odoherty@ucd.ie

${ }^{1}$ School of Agriculture and Food Science and Lyons Research Farm,

University College Dublin, Belfield, Dublin 4, Ireland

Full list of author information is available at the end of the article
}

(c) The Author(s). 2018 Open Access This article is distributed under the terms of the Creative Commons Attribution 4.0 International License (http://creativecommons.org/licenses/by/4.0/), which permits unrestricted use, distribution, and reproduction in any medium, provided you give appropriate credit to the original author(s) and the source, provide a link to the Creative Commons license, and indicate if changes were made. The Creative Commons Public Domain Dedication waiver (http://creativecommons.org/publicdomain/zero/1.0/) applies to the data made available in this article, unless otherwise stated. 
(Continued from previous page)

Conclusion: By examining (1) the effects of superovulation and (2) the effects of an in vitro system (oocyte maturation, fertilisation and embryo culture) we have identified that the assisted reproduction process of superovulation alone has the largest impact on the DNA methylome of subsequent embryos.

Keywords: Assisted reproduction technologies (ART), Epigenetics, DNA methylation, Embryo, Gene body, Bovine, Genomic imprinting, Reproduction, Development

\section{Background}

In mammalian livestock species, embryo transfer and other emerging technologies offer significant opportunities for improvements in reproductive efficiency and genetic selection [1]. Assisted Reproductive Technology (ART) treatments involve the isolation and manipulation of gametes and embryos, such as in vitro maturation (IVM), in vitro fertilization (IVF), intracytoplasmic sperm injection (ICSI), in vitro embryo culture (IVC) and hormonal stimulation (SOV). The long- and short-term implications associated with these technologies are not fully determined; however several studies suggest that they are not without complication [2-6]. Evidence that ARTs are not completely benign exists from analyses of bovine ART-derived embryos, which exhibit differences at morphological, physiological, transcriptional, chromosomal and metabolic levels compared to their in vivo-derived counterparts [7].

Epigenetic mechanisms such as chromatin remodelling, histone modification and DNA methylation are fundamental to successful gametogenesis and are required for normal embryonic progression [2, 8]. Of these, DNA methylation remains the most extensively studied; with previous work demonstrating that the appropriate establishment of DNA methylation patterns in gametes and early embryos is essential for normal development [9]. Genomic imprinting is a process that involves appropriate DNA methylation of differentially methylated regions (DMRs) of the maternal and paternally-derived genomes to facilitate parent-of-origin expression of a cohort of genes, many of which are involved with embryonic growth [10, 11]. Many reports detailing the impact of ARTs on genomic imprinting, specifically DNA methylation at imprinted gene DMRs, suggest ART induces aberrant methylation [12-18], while others indicate that the DMRs remain unaffected [19-22]. Investigations of the epigenetic impact of ovarian stimulation in mouse models indicate that imprint establishment and global methylation status in oocytes is not affected, but that maintenance of imprints post-fertilization is affected [22]. For example, DNA methylation analysis at chromosome 7 in single mouse in vitro cultured blastocysts has shown widespread aberrancies, when compared to in vivo samples [23]. Furthermore, analysis of blastocysts [24], mid-gestation placentas [25] and full term liver and brain tissue [26], derived from superovulated females, indicated altered DNA methylation and/or gene expression at candidate imprinted DMRs. Most recently, findings from an investigation using a mouse model suggest that individual ART procedures cumulatively increase placental morphological abnormalities and epigenetic perturbations [27]. A recent investigation by Saenz-de-Juano et al. demonstrated that embryos developed using an in vitro follicular culture (IFC) method inflicted no additional epigenetic alterations at a small number of imprinted genes (Snrpn, H19 and Mest) compared with conventional ovulation induction, suggesting that IFC is a suitable, patient-friendly alternative to ovarian stimulation [28].

With regard to in vitro embryo production, analysis of the methylation status of candidate imprints in IVM bovine and human oocytes revealed no or only marginal effects [20, 29, 30]. This data concurred with earlier findings in IVM-derived murine offspring, which showed that life span and most physiological and behavioural parameters were not impacted by IVM [31]. In contrast to the short exposure time to in vitro culture conditions that IVM entails, post fertilization IVC until blastocyst can last from 1 to 8 days (3-4 days in mice [28], 5-6 days in human [32] and 7-8 days in cattle [33]), therefore it is not surprising that it has been associated with impaired imprinting for several genes in murine blastocysts and placental murine tissues [16, 34, 35]. In cattle, several reports have been published detailing the impact of IVM, IVF and IVC on single, multiple or global gene expression patterns of bovine oocytes and embryos [4, 36-39]. Aberrant expression appears to persist beyond elongation and implantation $[40,41]$. The divergent transcriptomic data is likely to be associated with altered epigenetic regulation [6]. Similarly, the high mortality rates and morphological anomalies observed in surviving cloned calves [42-44] are likely due to erroneous epigenetic reprogramming, as severe hypomethylation of imprint DMRs [45-49] in tissues recovered at various stages of development from day 17 to full term has been reported. Most recently, analysis of kidney, brain, muscle, and liver of ART-derived (produced in vitro) day 105 large offspring syndrome (LOS) fetuses revealed dysregulation of imprinted gene expression, with the number of misregulated genes positively correlated with an increasing magnitude of overgrowth in LOS fetuses. DNA methylation 
analysis in these fetuses at the DMR of three imprinted genes, SNRPN, NNAT, and PLAGL1, also revealed some tissue specific aberrant methylation patterns [50].

Advances in genome-wide methylation analyses offer the opportunity to assess the effect of routine ART protocols on the global epigenetic landscape of gametes and embryos. Recently, the EmbryoGENE network at the University Laval, Quebec (http://emb-bioinfo.fsaa.ulaval.ca/) developed a microarray based methylation analysis platform for assessing genome wide methylation patterns using small quantities of DNA from bovine embryos [51]. This technology has been used to (1) demonstrate a link between S-adenosyl methionine supplementation, from the 8 cell stage until blastocyst, and DNA methylation in resultant blastocysts [52], (2) analyze the impact of different in vitro embryo culture lengths on DNA methylation of transferred embryos [53], (3) elucidate the effect of fatty acid exposure during oocyte maturation and embryo culture on blastocyst DNA methylation [54] and (4) identify differentially methylated loci in spermatozoa of monozygotic twin bulls [55]. Using this technology we evaluated the effect of oocyte maturation, fertilization and embryo development under in vitro (IVP) conditions, and the effect of ovarian hyperstimulation (SOV). Embryos were developed under these two conditions, separately, until day 7 (blastocyst stage) then transferred singly to recipient animals for recovery at day 17 (peri-implantation) for DNA methylation analysis. All IVP and SOV conceptuses were compared to the DNA methylation profiles of single ovulation in vivo conceptuses from non-stimulated synchronised animals (AI) (Fig. 1). Four differentially methylated gene bodies, identified on the EDMA array, were analyzed by pyrosequencing. Additionally, targeted analysis of DNA methylation at one paternally methylated (H19) and five maternally methylated (SNRPN, PLAGL1, PEG10, IGF2R, MEST) imprinted loci was also carried out in all IVP, SOV-derived and AI embryo samples. Ingenuity Pathway and gene expression analyses were performed to assess the functional implications of ART-induced differential DNA methylation.

\section{Results}

Total significantly differentially methylated loci associated with SOV and IVP

8134 loci were differentially methylated between AI and SOV-derived and IVP conceptuses. Taking a high stringency approach, only sequences with hybridization to both sense and matching anti-sense probes were analyzed (total 47,110 loci) and only those probes where both the sense and anti-sense probe achieved significance $(P \leq 0.05)$ and reached the fold-change threshold $(\geq 1.5)$ were considered to be differentially methylated. Thus only loci that had overlapping probes yielding the same signal i.e. loss or gain of methylation relative to control samples were recorded as differentially methylated; 3140 loci met these criteria (Table 1). Overall, SOV and IVP resulted in an increased number of loci that were more methylated than the control conceptuses, $67.7 \%$ of the loci had increased methylation whereas only $32.3 \%$ of the loci had lower levels of methylation than control AI conceptuses. To determine if either SOV or IVP regimes had a different impact on the methylation of resultant conceptuses the total number of differentially methylated loci from each treatment was investigated. The effect of treatment on the number of differentially methylated loci was much more pronounced in conceptuses generated by SOV $(77.3 \%)$ than those using in vitro techniques $(22.7 \%)$. Fewer than 10\% (312 loci) were consistent between SOV and IVP conceptuses (Fig. 2a). Analysis of methylation changes across three embryonic regions (ED, TE \& TP) in all IVP and SOV conceptuses revealed that the majority of methylation changes were occurring in the trophectoderm ( $\mathrm{ED}=1.2 \%$ vs $\mathrm{TE}=55.4 \%$ and $\mathrm{TP}=43.3 \%)$. The full list of probes and their genomic coordinates are outlined in Additional file 1 .

\section{Embryo production specific effects on DNA methylation}

The 3140 differentially methylated regions were queried to elucidate if there was any overlap between treatments or across embryonic regions. For this analysis the 39 loci significantly differentially methylated in the ED were omitted, as most of the significant differences were found in TE and TP tissue (3101 loci) comparisons. Significantly differentially methylated loci from IVP and SOV conceptuses were compared (Fig. 2b). The SOV conceptuses had 1250/1452 (86\%) regions that were unique to TE and the IVP conceptuses had 160/289 (55\%) regions that were unique to TE. For the TP samples 693/971 (72\%) and 198/389 (51\%) of the loci were differentially methylated following SOV or IVP, respectively. 90 regions in the TE and 158 in the TP regions were aberrantly methylated in both SOV and IVP conceptuses. There were 19 probes (y-axis, Fig. 3) that were significant in more than one contrast and showed changes in the direction of the effect. Most of the changes occurred between TE and TP contrasts, demonstrating that differential methylation direction can vary across both trophectoderm tissues.

\section{Underlying sequence features of differentially methylated loci}

Following the identification of sense-antisense probes that had statistically significant differences in methylation $(n=3140)$, their distribution across the genome was determined. As predicted from human array studies [56], the proportion of differentially methylated loci mapping within $\mathrm{CpG}$ islands was low, 36/3140 $=1.1 \%$ (Fig. 4 and Table 2). Given that we and others have shown that gene body methylation can facilitate 


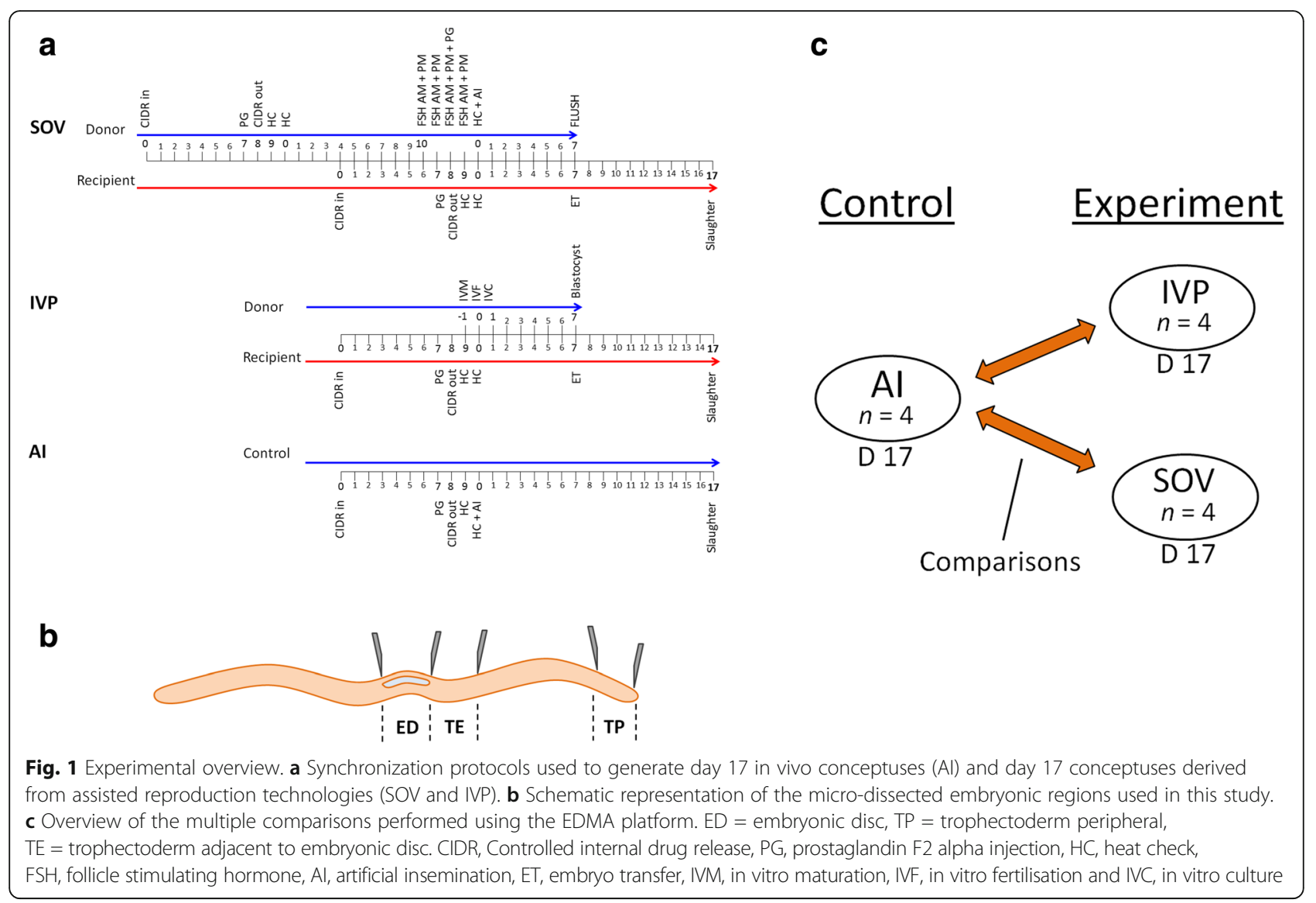

transcription [57-60], the number of significant probes that were located within intragenic regions (coding and non-coding regions within the transcribed sequence) was calculated (Table 2). Irrespective of production method (IVP or SOV), 968 of the 3140 probes mapped to intragenic regions (30.8\%), only a very small proportion $(13 / 968 ; 1.3 \%)$ were found in the ED, with the remaining probes being split between TP $(445 / 968 ; 46 \%)$ and TE $(510 / 968 ; 52.7 \%)$. The data was also mined to identify whether DNA methylation aberrancies were occurring at loci encoding microRNAs, molecules that

Table 1 Total number of differentially methylated probes

\begin{tabular}{lcccc}
\hline Region & Treatment & Up vs Al & Down vs Al & Total \\
\hline ED & SOV & 1 & 3 & 4 \\
& IVP & 6 & 29 & 35 \\
TE & SOV & 1316 & 136 & 1452 \\
& IVP & 164 & 125 & 289 \\
TP & SOV & 397 & 574 & 971 \\
& IVP & 243 & 146 & 389 \\
Total & & 2127 & 1013 & 3140 \\
\hline
\end{tabular}

$E D=$ embryonic disc, $T P=$ trophectoderm peripheral, $T E=$ trophectoderm adjacent to embryonic disc, $S O V=$ superovulation-derived conceptus, IVP = in vitro-derived conceptus are involved with post-transcriptional gene regulation [61]. Disrupted DNA methylation was detectable at a single miRNA (miRNA 2890), in the peripheral trophectoderm (TP) of superovulated conceptuses.

\section{Under-representation of differential methylation at CTCF loci}

The number of significant probes that were located in CTCF recognition sites was determined using computationally predicted CCCTC-binding factor (CTCF) sites and their coordinates transferred to the bosTau6 (UMD3.1) assembly, using the LiftOver tool from UCSC. A total number of 7 of the 3140 differentially methylated fragments were located within the predicted CTCF binding sites. This compares to 746 of the 48,530 CTCF recognition sites in the total set of significant fragments that were analyzed. This means we found a 7.5-fold under-representation of CTCF sites in the differentially methylated loci $(0.2 \%$ in differentially methylated fragments vs $1.5 \%$ in all fragments), which was highly significant $(p<1.3 \mathrm{e}-09$ by Proportional Test).

\section{Array validation}

The EDMA has been validated previously by pyrosequencing analysis of DNA isolated from sperm and 
a

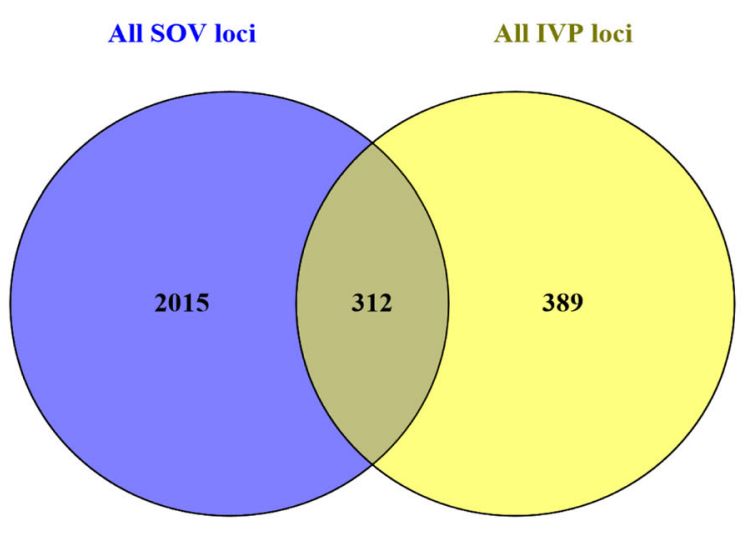

b

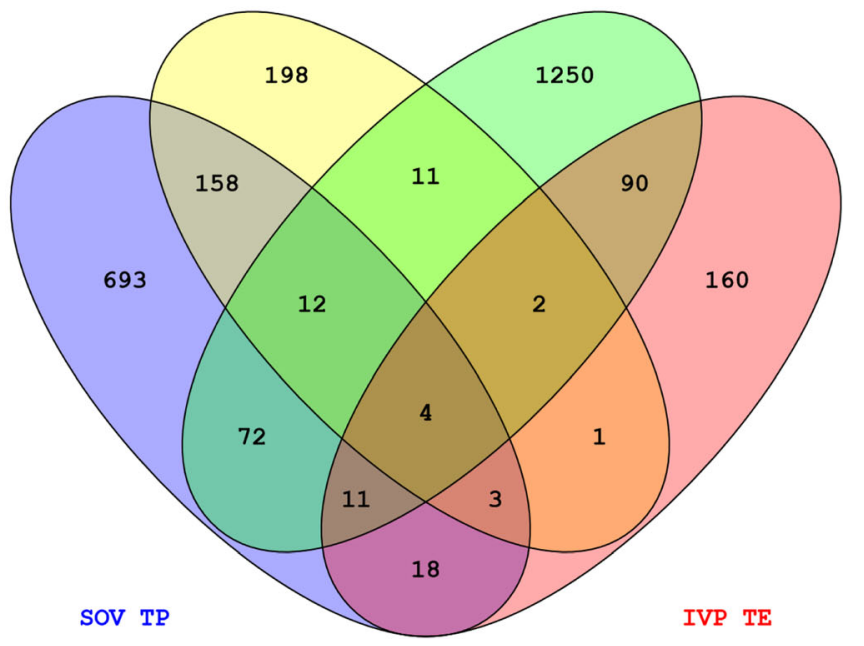

Fig. 2 a 2-way venn diagram representing overlap of differentially methylated loci between SOV and IVP conceptuses. Duplicate probes that were identified in multiple groups were removed, therefore the total number of loci for SOV and IVP is less than detailed in Table 1 , b 4-way venn diagram showing overlap of significant probes for the TE and TP tissues. Images generated using Venny http://bioinfogp.cnb.csic.es/ tools/venny/index.html)

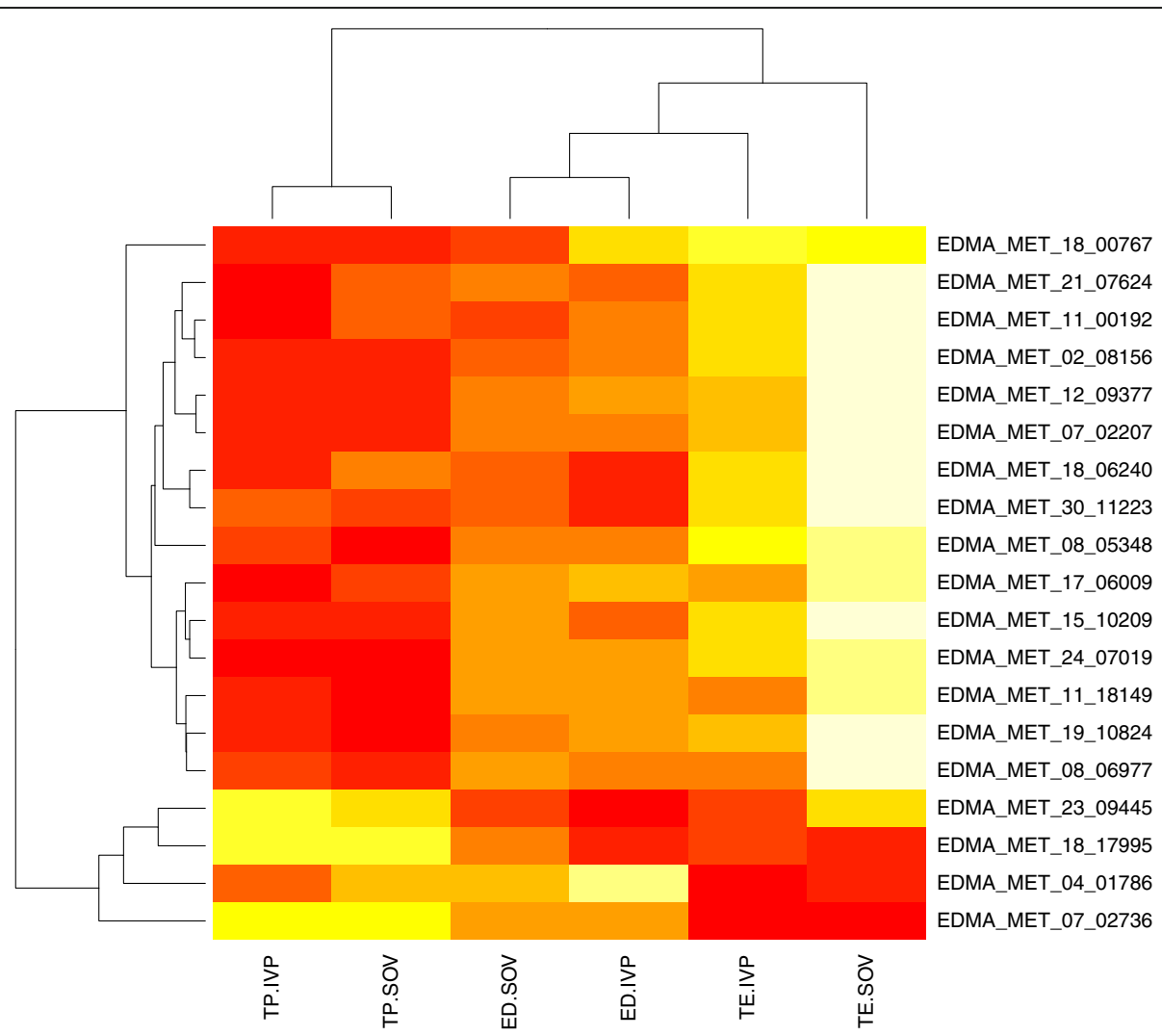

Fig. 3 Heatmap of significant probes that exhibit differences in methylation state and direction in different tissues. A small number of loci show differences in the direction of change in methylation in different embryonic regions $\mathrm{ED}=$ embryonic disc, $\mathrm{TP}=$ trophectoderm peripheral, $\mathrm{TE}=$ trophectoderm adjacent to embryonic disc, SOV = superovulation-derived embryo, IVP = in vitro-derived embryo. The ID of each probe is outlined on the right hand side of the map and their genomic location can be found at http://emb-bioinfo.fsaa.ulaval.ca/bioinfo/html/index.html 


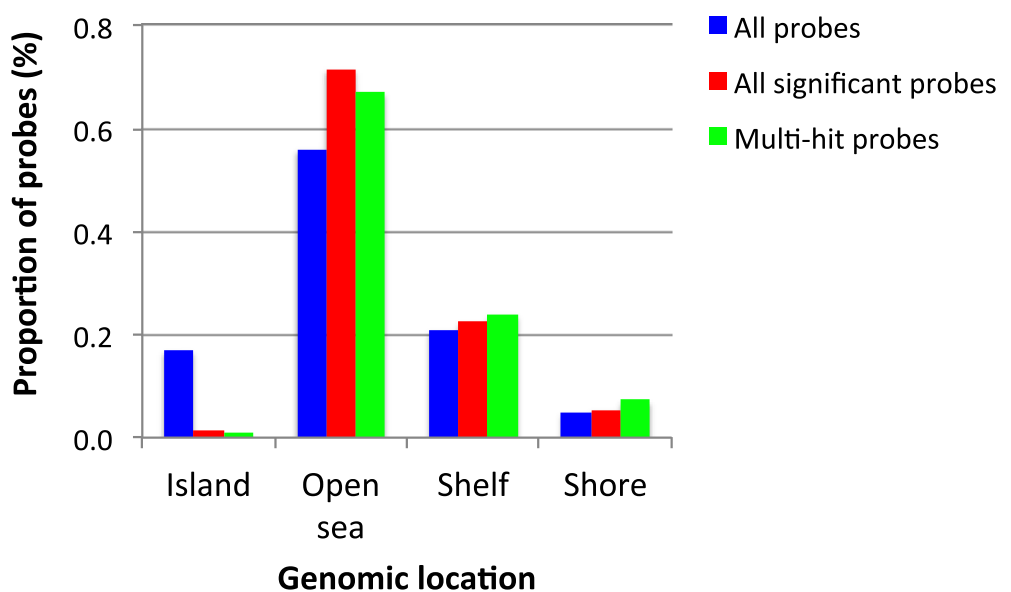

Fig. 4 Distribution of differentially methylated loci. Breakdown of the percentage of differentially methylated loci in each genomic location ( $C p G$ islands, Open sea, Shelf and Shore), where both sense and anti-sense probes were significant in at least one contrast. The parameters used to define CpG Island, Open Sea, Shelf and Shore are outlined in [51]

blastocyst samples [51]. In this study, DNA methylation was further analysed at four loci identified as being differentially methylated on the EDMA platform. Pyrosequencing assays were located within the intragenic regions of RNF7 (RNF7 has two assays covering separate CpGs - RNF7 assay 1 and RNF7 assay 2), GLTP, TRAPPC 9 and CRISPLD2. These loci were selected based on their fold-change, $P$-values and that the representative array probes contain at least one enzyme restriction site specific to the enzymes used for methyl-sensitive digestion during sample preparation for the array. They also represent comparisons of the following samples; SOV TE v AI TE, SOV TP v AI TP, IVP TE $v$ AI TE and IVP TP v AI TP. Pyrosequencing confirmed the direction of methylation changes at these loci (loss of methylation at each locus), with RNF7 assay 2 reaching significance $(P \leq 0.05)$ (Fig. 5$)$.

\section{DNA methylation analysis of imprinted genes}

The methylation status at six imprinted gene DMRs (SNRPN, PLAGL1, PEG10, IGF2R, MEST and H19) was determined by selective mining of the array output for probes located at imprinted loci (probe locations are outlined in Fig. 6 and Fig. 7a). None of the probes that mapped to imprinted genes were differentially methylated in the EDMA platform (adjusted $P$-value $\geq 0.05$ ). In a parallel experiment, pyrosequencing of the six imprinted genes was carried out. In general, the pyrosequencing results concurred with the array data, i.e. no significant differences (Fig. 6). However, the PLAGL1 and MEST DMRs showed some significant sites (Fig. 7b). The PLAGL1 DMR was differentially methylated in trophectoderm tissue from both SOV and IVP samples. CpGs at this locus were significantly more methylated in the TE (AI: $24.9 \%$ vs. SOV: $34 \%$ and IVP: $31.5 \%$ ) and TP (AI: $23.9 \%$ vs. SOV: $32.1 \%$ and IVP: $31.5 \%$ ) regions of day 17 ART-derived conceptuses, relative to AI conceptuses. Methylation at MEST was significantly lower in the ED of SOV samples when compared to both AI and IVP. Additionally, to identify any further putative imprinted genes that were differentially methylated in the current study we compared the aberrantly methylated loci from the array data with a previously published list of 105 genes known to be imprinted in human and mouse [50]. This revealed that five genes $(D D C, D H C R 7, S F M B T 2$,

Table 2 Differentially methylated probes mapping to gene bodies and CpG islands

\begin{tabular}{|c|c|c|c|c|c|c|}
\hline & ED SOV & TE SOV & TP SOV & ED IVP & TE IVP & TP IVP \\
\hline Total & 4 & 1452 & 971 & 35 & 289 & 389 \\
\hline CpG Island & 0 & 18 & 7 & 0 & 3 & 8 \\
\hline$\%$ in CpG Island & 0 & 1.2 & 0.7 & 0 & 1.04 & 2.1 \\
\hline Gene Body & 2 & 432 & 309 & 11 & 78 & 136 \\
\hline$\%$ in Gene Body & 50 & 29.8 & 31.8 & 31.4 & 27 & 35 \\
\hline Gene body up & 0 & 393 (91\%) & $132(43 \%)$ & 0 & $35(45 \%)$ & $85(62.5 \%)$ \\
\hline Gene body down & $2(100 \%)$ & $39(9 \%)$ & 177 (57\%) & $11(100 \%)$ & 43 (55\%) & $51(37.5 \%)$ \\
\hline
\end{tabular}

$E D=$ embryonic disc, $T P=$ trophectoderm peripheral, $T E=$ trophectoderm adjacent to embryonic disc, SOV = superovulationderived embryo, $I V P=$ in vitro-derived embryo 

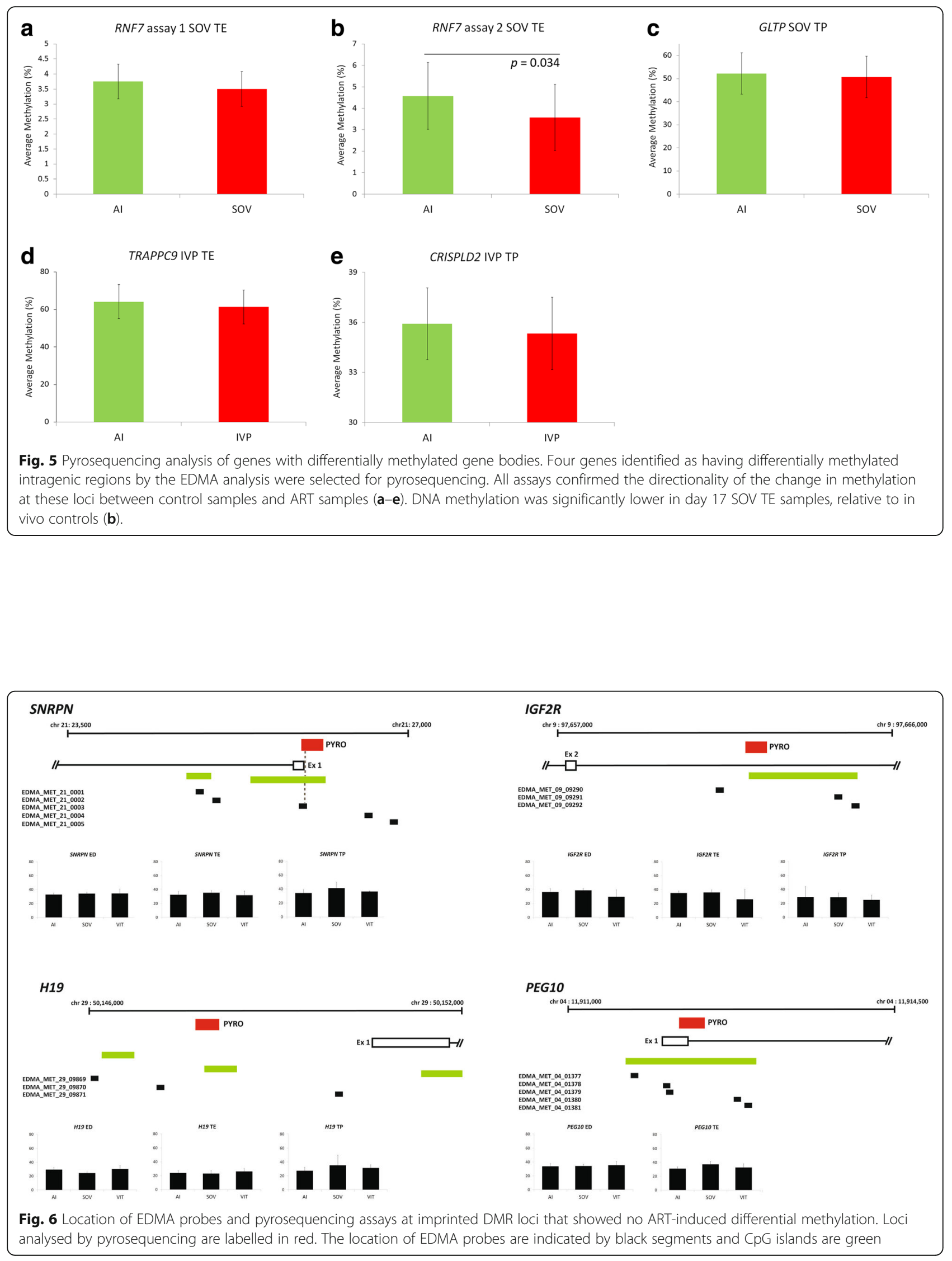


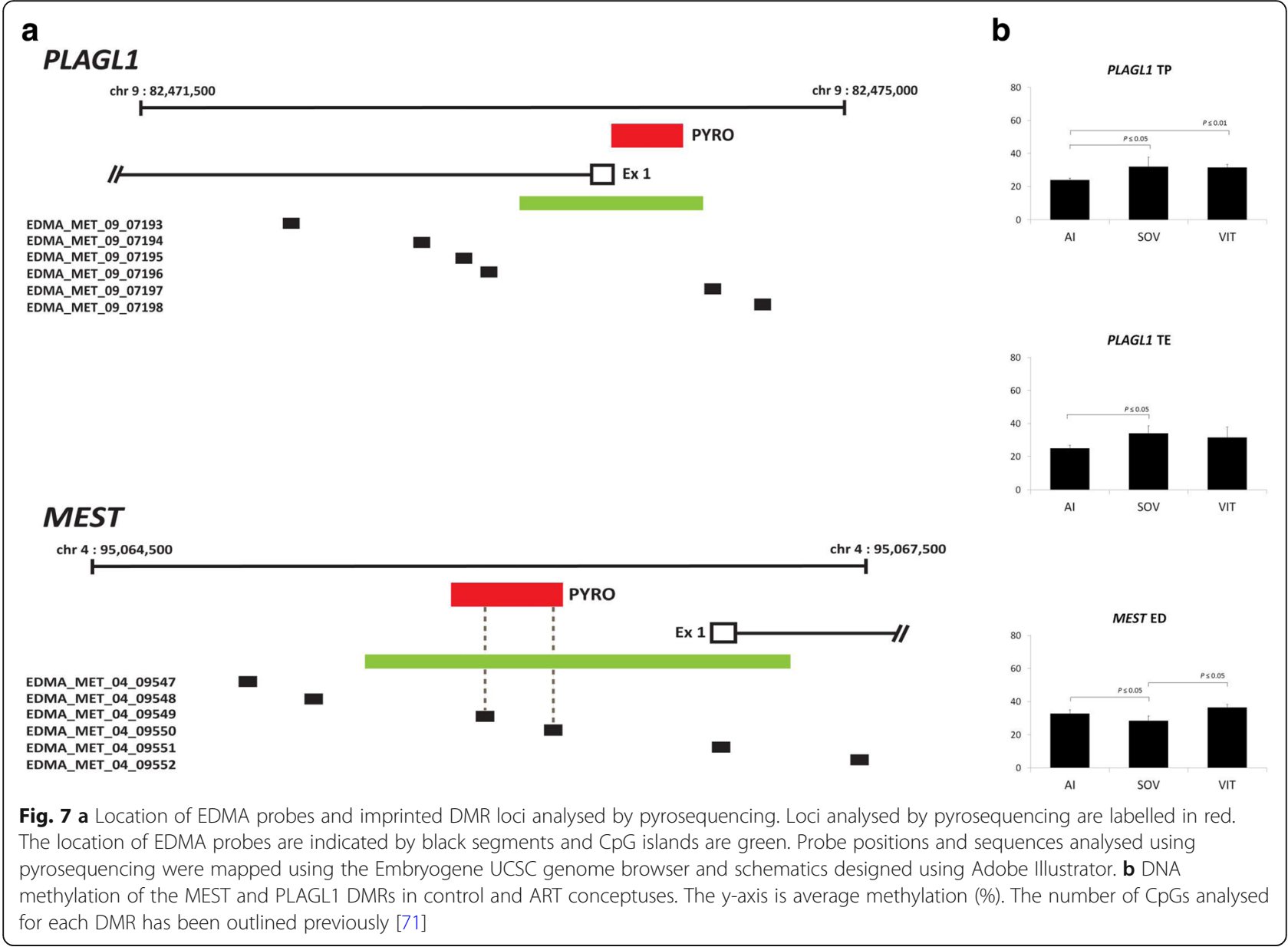

TCEB3 and TRAPPC9) were overlapping between the significantly differentially methylated genes identified on the array and the previously published reference list of known mammalian imprinted genes (Additional file 2).

\section{Functional implications of ART induced DNA methylation alterations}

To determine the potential impact of SOV and IVP-induced differential methylation, observed in this study, Ingenuity Pathway Analysis (IPA) and qPCR were performed to interrogate genes that had differential methylation confined within gene bodies of TE and TP samples. IPA results showed that genes populated categories including embryonic development, cellular development, tissue development, gene expression and organismal development; the top 7 ranked categories are presented in Table 3 and the complete IPA output is included in Additional file 3. Gene expression analysis identified a link between the loss of methylation at the TCEB3 locus, observed in SOV TE and IVP TE samples (Additional file 1), and down regulation of TCEB3 expression in SOV TE samples $(P=0.04732)$. qPCR results are summarized in Table 4 .

Table 3 Gene Ontology analysis of genes with differentially methylated gene bodies

\begin{tabular}{lccr}
\hline Rank & Category & Number of genes & $P$-value \\
\hline 1 & Cancer & 391 & $6.11 \times 10-09$ \\
2 & Molecular Transport & 148 & $4.84 \times 10-08$ \\
3 & Cellular Assembly and Organization & 148 & $1.01 \times 10-07$ \\
4 & Cellular Function and Maintenance & 195 & $1.01 \times 10-07$ \\
5 & Cell Morphology & 168 & $3.08 \times 10-07$ \\
6 & Organismal Development & 141 & $1.06 \times 10-05$ \\
7 & Cell Death and Survival & 218 & $1.10 \times 10-05$ \\
\hline
\end{tabular}


Table 4 qPCR analysis of imprinted genes and genes with ART-induced gene body methylation aberrancies

\begin{tabular}{|c|c|c|c|c|c|c|}
\hline Gene symbol (Chromosome) & Differential Methylation EDMA & NCBI Ref Seq ID & SOV TE & SOV TP & IVP TE & IVP TP \\
\hline TCEB3 (chr 2) & Gene body SOV TE and IVP TE & NM_001102333.1 & $0.047 \downarrow$ & 0.34 & 0.19 & 0.51 \\
\hline OCRL (chr X) & Gene body TE IVP and TE SOV & NM_001102191.2 & 0.08 & 0.25 & 0.12 & 0.28 \\
\hline ATP1A1 (chr 3) & Gene body TP SOV and TP IVP & NM_001076798.1 & 0.70 & 0.67 & 0.92 & 0.89 \\
\hline SNRPN (chr 21) & N/A & NM_001079797.1 & 0.63 & 0.51 & 0.15 & 0.16 \\
\hline H19 (chr 29) & N/A & NR_003958.2 & 0.62 & 0.32 & 0.88 & 0.45 \\
\hline
\end{tabular}

$[P$-values are given, significant values ( $p \leq 0.05$ unpaired, two tailed t-test) are underlined in bold]

The downwards arrow represents that the gene is downregulated compared to control (Al)

\section{Discussion}

Here we advance the field by comparing, separately, the impact of hormonal and in vitro manipulations of bovine gametes and early embryos on the DNA methylation of preimplantation conceptuses. This unique approach to studying the impact of these procedures on embryonic DNA methylation was performed using DNA from multiple embryonic regions of single conceptuses and compared to control DNA isolated from in vivo-derived conceptuses. Results from the current study provide evidence that both of these techniques are potentially altering genomic methylation patterns, compared to unstimulated in vivo control samples, but especially SOV.

Classically, DNA methylation has often been defined as a repressive genome modification associated with silencing gene expression [62, 63]. A number of studies have demonstrated that non-promoter DNA methylation (e.g. gene bodies and regulatory elements) may have an active role in regulating gene expression [57, 58, 64]. In this investigation a large proportion of the differentially methylated loci $(26.3-50 \%)$ were located within gene bodies and the direction of methylation differences at four gene bodies, between control and SOV-derived or IVP-conceptuses, was confirmed by pyrosequencing. We and others have also recently shown that decreasing gene body methylation at such genes through use of methyltransferase-deficient systems results in decreased transcription, highlighting a positive role for methylation in the gene body in facilitating transcription $[59,60,65]$. This implies that the altered gene body methylation observed in our SOV-derived and IVP conceptuses could indeed have functional consequences. Furthermore, in silico functional analysis of all the differentially methylated loci, within gene bodies of SOV-derived and IVP conceptuses, confirmed that the associated genes populated biological relevant categories (embryonic development, cellular development, tissue development, gene expression and organismal development) for this stage of mammalian development. Results from our qPCR experiments confirmed a possible link between differential gene body methylation (detected by EDMA) and gene expression, at the TCEB3 locus.
In the current study we also assessed the impact of SOV and IVP on DNA methylation at CpG islands and CTCF recognition sites. Both of these genomic features were underrepresented in loci that were differentially methylated following ART. Perturbations of DNA methylation at CGIs of tumor suppressor genes are characteristic of many cancers [57], while CTCF is fundamentally involved with connecting the gap between nuclear organization and gene expression, it also regulates several epigenetic processes, such as X chromosome inactivation, imprinting and non-coding RNA transcription $[66,67]$. Therefore, given the functional importance of these genetic elements, two hypotheses emerge, either of which would account for the underrepresentation of these loci in the set of differentially-methylated loci we identified: (1) incurring DNA methylation changes above a threshold level at these regions could result in embryonic lethality or, (2) CGIs and CTCF binding sites are more resistant to SOV or IVP-induced methylation changes. However, validation of either hypothesis requires further investigation.

The almost complete absence of differentially methylated loci in the ED region compared to the TE and TP regions, might suggest that either the $\mathrm{ED}$ is protected from methylation perturbations, or that such perturbations in this region of the embryo result in mortality. In addition to the observation that the majority of differentially methylated loci were within the trophectoderm regions, there were also a small number of probes showing directional differences in methylation, depending on whether they were in the TE or TP. The observation that the majority of the methylation differences occurred in the trophectoderm is intriguing. During implantation the trophectoderm engages directly with the mother's uterus giving rise to tissues of the placenta, creating an interface between mother and fetus that is essential for exchange of nutrients, gases, waste and maintenance of gestation [68]. These findings support the hypothesis in the literature that adverse pregnancy outcomes, following ART, arise from deficiencies in placental function [69].

As outlined earlier, the impact of ART on methylation and expression of imprinted genes remains divisive [12-22, $30,50,70]$. For this reason, we investigated the methylation 
of six previously characterized DMRs; IGF2R, PEG10, MEST, SNRPN, PLAGL1 and H19 [71, 72] and found no differences in methylation on the array or by pyrosequencing. However, pyrosequencing did identify significant changes in methylation at both PLAGL1 and MEST and PLAGL1 is under-represented by array probes. For PLAGL1 the lack of significant changes on the array is probably due to a lack of probes located within the DMR that was covered by pyrosequencing. The CGI spanning the $M E S T$ proximal promoter, first exon and part of the first intron was represented on the array by 3 probes, 2 of which directly overlapped the region analysed by pyrosequencing. The lack of a significant signal at these locations on the array could be, in part, due to the high stringency approach used to select significantly differentially methylated loci from the array or be due to a technical difference between array analysis and targeted analysis of methylation. This has been as discussed previously by others [73] and we have recently detailed the limitations of the EMDA platform [54]. In addition, although the EMDA platform is cost-effective, has a rapid turnaround time, a dedicated downstream analysis pipeline and has been specifically designed to assess DNA methylation patterns in bovine embryos using finite amounts of input DNA (1 - $10 \mathrm{ng})$ [51], it is not possible to get single nucleotide resolution maps of genome wide methylation patterns using this technology. This can be achieved using whole genome bisulfite sequencing (WGBS). Future investigations using this method will help to provide higher resolution profiles of DNA methylation in embryos generate using ART.

Five additional imprinted genes (DDC, DHCR7, SFMBT2, TCEB3 and TRAPPC9), identified as imprinted in human and mouse [50], were identified as having aberrant gene body methylation in SOV (DDC, DHCR7, SFMBT2, TCEB3 and TRAPPC9) and IVP (TCEB3) conceptuses here. This recently published study by Chen et al. identified aberrant methylation patterns and biallelic expression of imprinted genes in fetal organs of pregnancies following transfer of in vitro produced embryos. It was demonstrated that DNA methylation was perturbed at PLAGL1, NNAT and SNRPN. Furthermore, recent studies using the Illumina Infinium Human Methylation Array, pyrosequencing and qPCR to compare cord blood samples from ART and control pregnancies also revealed that the PLAGL1 locus is sensitive to ART manipulations $[74,75]$. The consensus between the current and earlier studies, that PLAGL1 is sensitive to ART-induced methylation changes, is consistent with observations of an association between ART and patients with the human disorder Beckwith-Wiedemann syndrome [76, 77], thus highlighting PLAGL1 as a key susceptibility marker to ART procedures.

\section{Conclusions}

In summary, both IVP and SOV procedures were associated with genome wide differences in embryonic DNA methylation to different extents. Superovulation treatment was the major cause of differential methylation in this study. Changes to DNA methylation was region specific; the embryonic disc showing almost no alterations compared to a significant number of differences in trophectoderm tissues. The differentially methylated loci tended to cluster within intragenic regions, suggesting a non-random effect, and are enriched for cancer, cell morphology and development. There was also an effect of ART on DNA methylation at a small number of imprinted genes and gene expression at the TCEB3 locus. Methylation differences at the PLAGL1 locus were apparent by pyrosequencing; this is congruent with observations in the literature demonstrating the influence of ART on DNA methylation at imprinted loci. Overall this study provides evidence that ART induces alterations to the embryonic methylome, in addition, many of these alterations appear to occur in an ART intervention, tissue and gene -specific manner. The majority of which were observed in the trophectoderm of SOV-derived conceptuses. These experiments demonstrate that embryos developing from the zygotic stage to the blastocyst stage in a modified environment (in vitro culture conditions or oviduct microenvironment containing multiple SOV-derived embryos) and transferred to a 'normal' environment retain aberrant epigenetic programming. The observed ART-induced DNA methylation differences may lead to misregulation of gene expression later in development, reducing developmental potential and contributing, in part, to health complications such as fetal overgrowth and large-offspring syndrome (LOS). Indeed, a recent study using WGBS has shown a link between DNA methylation differences and the expression of a small number of genes in skeletal muscle recovered from day $\sim 105$ bovine LOS foetuses [78]. Our study bolsters the importance of a non-rodent model, particularly the cow, for providing comparative data for the human IVF and developmental programming fields and provides a base for future high-resolution Whole Genome Bisulfite Sequencing studies investigating the impact of ARTs on the embryonic genome in cattle.

\section{Methods}

\section{Study design and number of comparisons}

The experimental design for embryo production is illustrated in Fig. 1a. Four day 17 conceptuses of each type (4 $\mathrm{x} \mathrm{AI}, 4 \times \mathrm{IVP}$ and $4 \times \mathrm{SOV}$ ) that were fully intact upon flushing from the uterus were retained for experimental analysis. Each embryo was dissected into the following sections, as outlined in Fig. 1b; the embryonic disc (ED) and trophectoderm - embryonic disc adjacent 
(TE) and trophectoderm peripheral (TP). The entire embryonic disc was trimmed and for the TE and TP approximately $1 \mathrm{~cm}$ sections were isolated. The rationale to interrogate these regions separately was based on previous investigations demonstrating that differences, such as differences in morphology and function, occur between regions adjacent to the embryonic disc and the periphery of the trophectoderm. Multiple statistical contrasts (Fig. 1c), comprising four biological replicates of each type of embryo and each embryonic region (ED, TE and TP), were carried out using the $400 \mathrm{~K}$ EmbryoGENE DNA Methylation Array (EDMA http://emb-bioin fo.fsaa.ulaval.ca/). This bovine-specific array contains $\sim 420,000$ probes mapping to 359,738 loci, surveying 20,355 gene-regions and 34,379 CpG islands).

\section{Preparation of conceptuses}

\section{Animal synchronization and embryo collection}

All animals were housed indoors in a slatted shed for the duration of the experiment and were fed a diet consisting of grass and maize silage supplemented with a standard beef ration. Cross-bred beef heifers (primarily Charolais beef heifers, or Simmental X Charolais and Limousin X Charolais crosses) were randomly assigned to be treated as unstimulated donors or recipients (i.e. single-ovulating, $n=20$ ) or superstimulated donors $(n=9)$. Artificial insemination and IVF were carried out using frozen thawed semen from the same bull to limit any potential variability that may be introduced by using spermatozoa from multiple bulls. Animals were slaughtered at a local abattoir 17 days following insemination or 10 days subsequent to embryo transfer, using standard practice.

\section{Unstimulated heifers}

Collection of control in vivo-derived bovine conceptuses was performed using a previously described synchronization protocol [79], denoting these control conceptuses as 'AI' is based on a previous investigation [80]. Briefly, heifers (approximately 18-24 months old) were synchronized using an 8-day Controlled Internal Drug Release device (CIDR 1.36 g, Pfizer, Sandwich, Kent, UK) with administration of a prostaglandin F2 $\alpha$ (PGF2 $\alpha$ ) analogue (2 ml Estrumate; Schering-Plough Animal Health, Hertfordshire, UK, equivalent to $0.5 \mathrm{mg}$ cloprostenol) injection one day prior to removal of the CIDR. Animals were examined for estrus four times daily, from $36 \mathrm{~h}$ following PGF $2 \alpha$ injection. Animals in standing estrus between 36 and $60 \mathrm{~h}$ were inseminated using frozen thawed semen. Reproductive tracts were recovered within $30 \mathrm{~min}$ of slaughter from animals on day 17 post insemination, and transported on ice. Conceptuses were recovered from reproductive tracts by flushing both uterine horns with $40 \mathrm{ml}$ of PBS containing 5\% fetal calf serum (FCS). All intact conceptuses were washed and dissected in PBS and then immediately snap frozen using liquid nitrogen.

\section{Superstimulated donor heifers}

Procedures for superstimulation were as described by Rizos et al. [81]. Beginning on day 10 of a synchronised oestrous cycle, heifers were superstimulated with a total of 455 IU FSH (13 ml Folltropin; Bioniche, Inverin, Galway, Ireland) given as twice daily intramuscular injections over 4 days on a decreasing dose schedule. Luteolysis was induced with $2 \mathrm{ml}$ Estrumate (PGF2 $\alpha$ ) given on day 12 with the sixth injection of follicle stimulating hormone (FSH). All heifers received $2.5 \mathrm{ml}$ Receptal $(\mathrm{GNRH})$ at $40 \mathrm{~h}$ after PGF2 $\alpha$, the expected time of the luteinizing hormone (LH) surge [82]. Animals seen in standing estrus between 36 and $60 \mathrm{~h}$ were inseminated using frozen thawed semen. Inseminated animals were slaughtered and embryos recovered from reproductive tracts on day 7 and used for same day embryo transfer.

\section{In vitro embryo production}

The techniques for producing embryos in vitro have been described in detail previously [81], reagents were purchased from Sigma (Sigma-Aldrich, Ireland). Immature cumulus-oocyte complexes (COCs) were obtained by aspirating follicles from the ovaries of heifers and cows collected at killing. COCs were matured for $24 \mathrm{~h}$ in TCM-199 supplemented with 10\% (v/v) FCS and $10 \mathrm{ng} / \mathrm{ml}$ epidermal growth factor at $39{ }^{\circ} \mathrm{C}$ under an atmosphere of $5 \% \mathrm{CO}_{2}$ in air with maximum humidity. For IVF, matured COCs were inseminated with frozen-thawed Percoll-separated bull sperm at a concentration of $1 \times 10^{6}$ spermatozoa/ml. Gametes were co-incubated at $39{ }^{\circ} \mathrm{C}$ under an atmosphere of $5 \% \mathrm{CO}_{2}$ in air with maximum humidity. Semen from the same bull was used for all experiments. At $\sim 20 \mathrm{~h}$ post-insemination (hpi), presumptive zygotes were denuded and cultured in groups of 50 in $500 \mu$ l synthetic oviduct fluid media (SOF) supplemented with 5\% FCS. Cleavage rate was recorded at $48 \mathrm{hpi}$ and blastocyst development recorded at day 7 post-insemination (pi).

\section{Unstimulated recipient heifers and embryo transfer}

Control animals (AI) were oestrous synchronized, as described above, artificially inseminated on detection of estrus and slaughtered 17 days post insemination. Oestrous synchronised recipient animals were randomly assigned to receive a day 7 blastocyst stage embryo recovered from a stimulated heifer $(\mathrm{SOV})$ or produced in vitro (IVP), 7 days following detection of estrus. Recipient animals were slaughtered 10 days post embryo transfer and conceptuses were recovered from reproductive tracts on day 17 of embryo development. 


\section{Sample preparation}

Day 17 conceptuses were processed for methylation array analysis by dissecting three embryonic regions from all control (AI) and treatment group samples (SOV and IVP) immediately after recovery from the reproductive tract. These regions were as follows: the embryonic disc (ED); the trophectoderm region directly adjacent to the embryonic disc (TE); and the peripheral tip of the elongated day 17 embryo (TP) (Fig. 1b). Genomic DNA and total RNA were isolated from single, dissected day 17 conceptuses using the AllPrep DNA/RNA Micro Kit (Qiagen, Manchester, UK) according to the manufacturers' guidelines. DNA samples were quantified using a Qubit dsDNA HS assay kit (Invitrogen ${ }^{\text {тм }}$, ThermoFisher Scientific Ltd., Dublin, Ireland). $10 \mathrm{ng}$ of DNA from each sample was prepared for the array exactly as outlined in [51]. $100 \mathrm{ng}$ total RNA from each region of all conceptuses and converted to cDNA as described previously [83].

\section{Microarray}

For a complete outline of microarray design and probe locations see [51, 84] and the EmbryoGENE UCSC Genome Browser (http://emb-bioinfo.fsaa.ulaval.ca/bioinfo/ html/index.html). A total number of 36 separate amplifications, comprising three regions (ED, TE, TP) from each of 12 conceptuses $(4 \times \mathrm{AI}, 4 \times \mathrm{SOV}$ and $4 \times \mathrm{IVP})$, were analysed in the present study. Quality control plots for all samples generated after EDMA microarray hybridization and data analysis are included in Additional file 4. The microarrays were processed using a custom pipeline outlined in [51]. The heatmap in Fig. 3 was generated in $\mathrm{R}$ using the heatmap function.

\section{EDMA data analysis}

EDMA data was analysed as previously outlined [51] using the Limma package from Bioconductor [85, 86]. LOESS intra-array normalisation and quantile inter-array scale normalisations were performed. Normalised data was then fitted to a linear model and tested for differential methylation using Bayesian statistics. DNA methylation differences were considered significant when the $P$ value was $<0.05$ and the absolute log 2 fold change threshold was $\geq 1.5$. Eigen values were used to compare groups using the Bioconductor package MADE4 [87].

\section{Pyrosequencing and qPCR}

Methylation analysis of six imprinted gene DMRs (SNRPN, PLAGL1, PEG10, IGF2R, MEST and H19) and four gene body regions identified as differentially methylated using the EDMA platform (RNF7, GLTP, TRAPPC9 and CRISPLD2) was performed using pyrosequencing, as described previously $[83,88]$. Briefly, a subset of tissue samples, collected as described above, were snap frozen, according to embryonic region, in $6 \mu \mathrm{l}$ PBS and stored at $-80{ }^{\circ} \mathrm{C}$. Prior to bisulfite PCR and pyrosequencing, samples were thawed, homogenised by vortexing for $1 \mathrm{~min}$ and $1 \mu \mathrm{l}$ was removed for bisulfite modification of DNA using the EZ DNA methylation Direct kit, Zymo Research, USA. Modified DNA was eluted in $42 \mu$ l elution buffer (preheated to $50{ }^{\circ} \mathrm{C}$ ) and $6 \mu \mathrm{l}$ was used as template in PCR reactions. For PCR conditions and primer sequences see [71, 72]. RNF7, GLTP, TRAPPC9 and CRISPLD2 primers are outlined in Additional file 5: Table S1. Methylation values were used a continuous variables for statistical analysis. Sample group means for each gene were compared using ANOVA followed by post-hoc $t$-tests using a Tukey's honest significant difference (HSD) multiple testing correction threshold of $\leq 0.05$. For each gene, analysis of residual values (Q-Q plots and Anderson-Darling tests) showed that all data were normally distributed. All statistical analyses were performed using the Minitab version 16 software package (Minitab Inc., PA, USA). qPCR was carried out in $15 \mu \mathrm{l}$ reactions containing $7.5 \mu \mathrm{l}$ Fast Sybergreen mastermix (Applied Biosystems, Foster City, CA, USA), $0.3 \mu \mathrm{m}$ of each primer and $5 \mu \mathrm{l}$ of a 1/10 dilution of cDNA. Raw CT values were imported into qbase ${ }^{\text {plus }}$ (Biogazzelle, Zwijnaarde, Belgium) were data was calibrated, normalised and expression values (CNRQ) for each gene was determined. Target genes, TCEB3, $O C R L$ and $A T P 1 A 1$, were selected as they were shown to be differentially methylated in at least two comparisons on the array. SNRPN and $H 19$ were also included as they are two of the most extensively studied imprinted genes. Target genes were normalised using two stable reference genes, $H 3 F 3 A$ and GAPDH (qPCR primers are listed in Additional file 5: Table S2). Statistical analysis for each gene (unpaired, two tailed t-tests) was carried out using the stat wizard function in qbase $\mathrm{plus}^{\text {lus }}$

\section{IPA analyses}

Ingenuity Systems Pathway Analysis (IPA; Ingenuity Systems, Redwood City, CA, USA) was used to identify canonical pathways and functional processes of biological importance within the lists of all differentially methylated regions that were located within gene bodies. Gene bodies were defined as all coding and non-coding regions within the transcribed sequence. Intensity on the array does not necessarily match methylation pattern or level for the complete gene-defined region. Functional analysis of differentially methylated loci, within gene bodies, was performed to characterize biological processes that could potentially be affected by ART. Right-tailed Fisher's exact tests were used to calculate a $P$-value for each of the biological functions assigned to a list of differentially methylated gene bodies. 


\section{Additional files}

Additional file 1: Full list of differentially methylated probes and their genomic coordinates. (XLS $820 \mathrm{~kb}$ )

Additional file 2: Comparison of differentially methylated genes with previously published imprinted genes. (XLS 28 kb)

Additional file 3: IPA output. (XLS $72 \mathrm{~kb}$ )

Additional file 4: Quality control plots for all samples generated after EDMA microarray hybridization and data analysis. (PDF 2803 kb)

Additional file 5: Table S1. Pyrosequencing primers used for array validation. Table S2. Primers used for gene expression analysis. (DOCX $17 \mathrm{~kb})$

\section{Abbreviations}

Al: Artificially inseminated; ART: Assisted reproductive technologies; CGI(s): CpG island(s); CIDR: Controlled internal drug release device; COCs: Cumulus-oocyte complexes; $\mathrm{CpG}(\mathrm{s})$ : Cytosine guanine dinucleotide; CTCF: CCCTC-Binding Factor (Zinc Finger Protein); DMR(s): Differentially methylated region(s): DNA: Deoxyribonucleic acid; ED: Embryonic disc; EDMA: EmbryoGENE DNA Methylation Array; FCS: Fetal calf serum; FSH: Follicle stimulating hormone; GnRH: Gonadotropin releasing hormone; hpi: hours post-insemination; ICSI: Intracytoplasmic sperm injection; IFC: In vitro follicle culture; IPA: Ingenuity pathway analysis; IVF: In vitro fertilisation IVM: In vitro maturation; IVP: In vitro produced; LH: Leutinizing hormone; LOS: Large offspring syndrome; PBS: Phosphate buffered saline; PGF2a: Prostaglandin F2a; qPCR: quantitative real time PCR; SOF: Synthetic oviduct fluid; SOV: Superovulation-derived; TCM-199: Tissue culture media 199; TE: Trophectoderm adjacent to the embryonic disc; TP: Peripheral trophectoderm; UCSC: University of California, Santa Cruz

\section{Acknowledgements}

The authors would like to thank the technical staff, in particular Mary Wade and Pat Duffy, at the UCD IVF facility, Lyons Research Farm, Dublin, Ireland.

\section{Funding}

This worked was supported by Science Foundation Ireland (SFI) grant number 07/SRC/B1156 and a grant from the Natural Sciences and Engineering Research Council of Canada (grant number: NETGP-340825-06) This grant was awarded from the Strategic Research Network program supporting the EmbryoGENE Network (http://emb-bioinfo.fsaa.ulaval.ca/).

\section{Availability of data and materials}

All data supporting the results reported in this article can be found in the additional files.

\section{Authors' contributions}

AOD and TF conceived and designed the study. AOD, TF, AA-N performed the animal work and collected all samples. AOD, RI, DG and DM performed the experiments. AOD, PMG, DM, and EF analysed the data. $A O D$ was the major contributor in writing the manuscript, supported with comments from TF and CPW. CR and MAS provided the array technology and contributed to manuscript preparation. All authors read and approved the final manuscript.

\section{Ethics approval and consent to participate}

All experimental procedures involving animals were licensed by the Department of Health and Children, Ireland, in accordance with the Cruelty to Animals Act, 1897, and the European Community Directive 86/609/EC. All procedures were sanctioned by the University College Dublin, Ireland Animals Research Ethics Committee. Animals were processed in a commercial abattoir.

\section{Competing interests}

The authors declare that there are no competing of interest.

\section{Publisher's Note}

Springer Nature remains neutral with regard to jurisdictional claims in published maps and institutional affiliations.

\section{Author details}

${ }^{1}$ School of Agriculture and Food Science and Lyons Research Farm, University College Dublin, Belfield, Dublin 4, Ireland. ${ }^{2}$ Biomedical Sciences Research Institute, University of Ulster, Coleraine, UK. ${ }^{3}$ Centre de Recherche en Biologie de la Reproduction (CRBR), Département des Sciences Animales, Université Laval, Québec, Qc, Canada. ${ }^{4}$ Department of Animal and Poultry Science, School of Agriculture, Virginia Polytechnic Institute and State University, Blacksberg, VA, USA

Received: 15 November 2017 Accepted: 22 May 2018

Published online: 05 June 2018

\section{References}

1. Hansen PJ. Current and future assisted reproductive technologies for mammalian farm animals. Adv Exp Med Biol. 2014;752:1-22.

2. Bourc'his D, Xu GL, Lin CS, Bollman B, Bestor TH. Dnmt3L and the establishment of maternal genomic imprints. Science. 2001;294(5551):2536-9.

3. Davies MJ, Moore VM, Willson KJ, van Essen P, Priest K, Scott H, Haan EA, Chan A. Reproductive technologies and the risk of birth defects. N Engl J Med. 2012;366(19):1803-13.

4. Halliday JL, Ukoumunne OC, Baker HW, Breheny S, Jaques AM, Garrett C, Healy D, Amor D. Increased risk of blastogenesis birth defects, arising in the first 4 weeks of pregnancy, after assisted reproductive technologies. Hum Reprod. 2010;25(1):59-65.

5. Hansen M, Bower C, Milne E, de Klerk N, Kurinczuk JJ. Assisted reproductive technologies and the risk of birth defects-a systematic review. Hum Reprod 2005:20(2):328-38

6. Urrego R, Rodriguez-Osorio N, Niemann H. Epigenetic disorders and altered gene expression after use of assisted reproductive technologies in domestic cattle. Epigenetics. 2014;9(6):803-15

7. Lonergan P, Fair T. In vitro-produced bovine embryos: dealing with the warts. Theriogenology. 2008;69(1):17-22

8. Rideout WM 3rd, Eggan K, Jaenisch R. Nuclear cloning and epigenetic reprogramming of the genome. Science. 2001;293(5532):1093-8.

9. Messerschmidt DM, Knowles BB, Solter D. DNA methylation dynamics during epigenetic reprogramming in the germline and preimplantation embryos. Genes Dev. 2014;28(8):812-28.

10. Barlow DP. Genomic imprinting: a mammalian epigenetic discovery model. Annu Rev Genet. 2011:45:379-403.

11. Bartolomei MS, Ferguson-Smith AC. Mammalian genomic imprinting. Cold Spring Harb Perspect Biol. 2011;3(7). https://doi.org/10.1101/ cshperspect.a002592.

12. Kerjean A, Couvert P, Heams T, Chalas C, Poirier K, Chelly J, Jouannet P, Pald A, Poirot C. In vitro follicular growth affects oocyte imprinting establishment in mice. Eur J Hum Genet. 2003;11(7):493-6.

13. Fauque $P$, Jouannet $P$, Lesaffre $C$, Ripoche MA, Dandolo L, Vaiman D, Jammes $\mathrm{H}$. Assisted reproductive technology affects developmental kinetics, $\mathrm{H} 19$ imprinting control region methylation and $\mathrm{H} 19$ gene expression in individual mouse embryos. BMC Dev Biol. 2007;7:116.

14. Cox GF, Burger J, Lip V, Mau UA, Sperling K, Wu BL, Horsthemke B. Intracytoplasmic sperm injection may increase the risk of imprinting defects. Am J Hum Genet. 2002:71(1):162-4.

15. Gicquel C, Gaston V, Mandelbaum J, Siffroi JP, Flahault A, Le Bouc Y. In vitro fertilization may increase the risk of Beckwith-Wiedemann syndrome related to the abnormal imprinting of the KCN1OT gene. Am J Hum Genet. 2003;72(5):1338-41.

16. Mann MR, Lee SS, Doherty AS, Verona RI, Nolen LD, Schultz RM, Bartolomei MS. Selective loss of imprinting in the placenta following preimplantation development in culture. Development. 2004:131(15):3727-35.

17. Katari S, Turan N, Bibikova M, Erinle O, Chalian R, Foster M, Gaughan JP, Coutifaris C, Sapienza C. DNA methylation and gene expression differences in children conceived in vitro or in vivo. Hum Mol Genet, 2009:18(20):3769-78.

18. Market-Velker BA, Zhang L, Magri LS, Bonvissuto AC, Mann MR. Dual effects of superovulation: loss of maternal and paternal imprinted methylation in a dose-dependent manner. Hum Mol Genet. 2010;19(1):36-51. 
19. Anckaert E, Adriaenssens T, Romero S, Dremier S, Smitz J. Unaltered imprinting establishment of key imprinted genes in mouse oocytes after in vitro follicle culture under variable follicle-stimulating hormone exposure. Int J Dev Biol. 2009;53(4):541-8.

20. Anckaert E, De Rycke M, Smitz J. Culture of oocytes and risk of imprinting defects. Hum Reprod Update. 2013;19(1):52-66.

21. Anckaert E, Romero S, Adriaenssens T, Smitz J. Effects of low methyl donor levels in culture medium during mouse follicle culture on oocyte imprinting establishment. Biol Reprod. 2010;83(3):377-86.

22. Denomme MM, Zhang L, Mann MR. Embryonic imprinting perturbations do not originate from superovulation-induced defects in DNA methylation acquisition. Fertil Steril. 2011;96(3):734-8. e732

23. Wright K, Brown L, Brown G, Casson P, Brown S. Microarray assessment of methylation in individual mouse blastocyst stage embryos shows that in vitro culture may have widespread genomic effects. Hum Reprod. 2011;26(9):2576-85.

24. Market-Velker BA, Fernandes AD, Mann MR. Side-by-side comparison of five commercial media systems in a mouse model: suboptimal in vitro culture interferes with imprint maintenance. Biol Reprod. 2010;83(6):938-50.

25. Fortier AL, Lopes FL, Darricarrere N, Martel J, Trasler JM. Superovulation alters the expression of imprinted genes in the midgestation mouse placenta. Hum Mol Genet. 2008;17(11):1653-65.

26. de Waal E, Yamazaki Y, Ingale P, Bartolomei MS, Yanagimachi R, McCarrey JR. Gonadotropin stimulation contributes to an increased incidence of epimutations in ICSI-derived mice. Hum Mol Genet. 2012;21(20):4460-72.

27. de Waal E, Vrooman LA, Fischer E, Ord T, Mainigi MA, Coutifaris C, Schultz RM, Bartolomei MS. The cumulative effect of assisted reproduction procedures on placental development and epigenetic perturbations in a mouse model. Hum Mol Genet. 2015;24(24):6975-85.

28. Saenz-de-Juano MD, Billooye K, Smitz J, Anckaert E. The loss of imprinted DNA methylation in mouse blastocysts is inflicted to a similar extent by in vitro follicle culture and ovulation induction. Mol Hum Reprod. 2016;22(6):427-41.

29. Heinzmann J, Hansmann T, Herrmann D, Wrenzycki C, Zechner U, Haaf T, Niemann $\mathrm{H}$. Epigenetic profile of developmentally important genes in bovine oocytes. Mol Reprod Dev. 2011;78(3):188-201.

30. Kuhtz J, Romero S, De Vos M, Smitz J, Haaf T, Anckaert E. Human in vitro oocyte maturation is not associated with increased imprinting error rates at LIT1, SNRPN, PEG3 and GTL2. Hum Reprod. 2014;29(9):1995-2005.

31. Eppig JJ, O'Brien MJ, Wigglesworth K, Nicholson A, Zhang W, King BA. Effect of in vitro maturation of mouse oocytes on the health and lifespan of adult offspring. Hum Reprod. 2009;24(4):922-8.

32. Glujovsky D, Blake D, Farquhar C, Bardach A. Cleavage stage versus blastocyst stage embryo transfer in assisted reproductive technology. The Cochrane database of systematic reviews. 2012;7:CD002118.

33. Sirard MA, Coenen K. In vitro maturation and embryo production in cattle. Methods Mol Biol. 2006;348:35-42.

34. Rivera RM, Stein P, Weaver JR, Mager J, Schultz RM, Bartolomei MS. Manipulations of mouse embryos prior to implantation result in aberrant expression of imprinted genes on day 9.5 of development. Hum Mol Genet. 2008;17(1):1-14.

35. Fernandez-Gonzalez R, Moreira P, Bilbao A, Jimenez A, Perez-Crespo M, Ramirez MA, Rodriguez De Fonseca F, Pintado B, Gutierrez-Adan A. Longterm effect of in vitro culture of mouse embryos with serum on mRNA expression of imprinting genes, development, and behavior. Proc Natl Acad Sci U S A. 2004;101(16):5880-5.

36. Corcoran D, Fair T, Park S, Rizos D, Patel OV, Smith GW, Coussens PM, Ireland JJ, Boland MP, Evans AC, et al. Suppressed expression of genes involved in transcription and translation in in vitro compared with in vivo cultured bovine embryos. Reproduction. 2006;131(4):651-60.

37. Lonergan P, Fair T, Corcoran D, Evans AC. Effect of culture environment on gene expression and developmental characteristics in IVF-derived embryos. Theriogenology. 2006;65(1):137-52.

38. Thelie A, Papillier P, Pennetier S, Perreau C, Traverso JM, Uzbekova S, Mermillod P, Joly C, Humblot P, Dalbies-Tran R. Differential regulation of abundance and deadenylation of maternal transcripts during bovine oocyte maturation in vitro and in vivo. BMC Dev Biol. 2007;7:125.

39. Gad A, Hoelker M, Besenfelder U, Havlicek V, Cinar U, Rings F, Held E, Dufort I, Sirard MA, Schellander K, et al. Molecular mechanisms and pathways involved in bovine embryonic genome activation and their regulation by alternative in vivo and in vitro culture conditions. Biol Reprod. 2012;87(4):100

40. Betsha S, Hoelker M, Salilew-Wondim D, Held E, Rings F, Grosse-Brinkhause C, Cinar MU, Havlicek V, Besenfelder U, Tholen E, et al. Transcriptome profile of bovine elongated conceptus obtained from SCNT and IVP pregnancies. Mol Reprod Dev. 2013;80(4):315-33.

41. Salilew-Wondim D, Tesfaye D, Hossain M, Held E, Rings F, Tholen E, Looft C, Cinar U, Schellander K, Hoelker M. Aberrant placenta gene expression pattern in bovine pregnancies established after transfer of cloned or in vitro produced embryos. Physiol Genomics. 2013;45(1):28-46.

42. Hill JR, Burghardt RC, Jones K, Long CR, Looney CR, Shin T, Spencer TE, Thompson JA, Winger QA, Westhusin ME. Evidence for placental abnormality as the major cause of mortality in first-trimester somatic cell cloned bovine fetuses. Biol Reprod. 2000;63(6):1787-94.

43. Edwards JL, Schrick FN, McCracken MD, van Amstel SR, Hopkins FM, Welborn MG, Davies CJ. Cloning adult farm animals: a review of the possibilities and problems associated with somatic cell nuclear transfer. Am J Reprod Immunol. 2003;50(2):113-23.

44. Lee GS, Hyun SH, Kim HS, Kim DY, Lee SH, Lim JM, Lee ES, Kang SK, Lee BC, Hwang WS. Improvement of a porcine somatic cell nuclear transfer technique by optimizing donor cell and recipient oocyte preparations. Theriogenology. 2003;59(9):1949-57.

45. Lucifero D, Suzuki J, Bordignon V, Martel J, Vigneault C, Therrien J, Filion F, Smith LC, Trasler JM, Bovine SNRPN. Methylation imprint in oocytes and day 17 in vitro-produced and somatic cell nuclear transfer embryos. Biol Reprod. 2006;75(4):531-8.

46. Suzuki J Jr, Therrien J, Filion F, Lefebvre R, Goff AK, Smith LC. In vitro culture and somatic cell nuclear transfer affect imprinting of SNRPN gene in pre- and post-implantation stages of development in cattle. BMC Dev Biol. 2009;9:9.

47. Curchoe $\mathrm{CL}$, Zhang S, Yang L, Page R, Tian XC. Hypomethylation trends in the intergenic region of the imprinted IGF2 and $\mathrm{H} 19$ genes in cloned cattle. Anim Reprod Sci. 2009;116(3-4):213-25

48. Couldrey C, Lee RS. DNA methylation patterns in tissues from mid-gestation bovine foetuses produced by somatic cell nuclear transfer show subtle abnormalities in nuclear reprogramming. BMC Dev Biol. 2010;10:27.

49. Dyer SJ. International estimates on infertility prevalence and treatment seeking: potential need and demand for medical care. Hum Reprod. 2009;24(9):2379-80. author reply 2380-2373

50. Chen Z, Hagen DE, Elsik CG, Ji T, Morris CJ, Moon LE, Rivera RM. Characterization of global loss of imprinting in fetal overgrowth syndrome induced by assisted reproduction. Proc Natl Acad Sci U S A. 2015;112(15): 4618-23.

51. Shojaei Saadi HA, O'Doherty AM, Gagne D, Fournier E, Grant JR, Sirard MA Robert C. An integrated platform for bovine DNA methylome analysis suitable for small samples. BMC Genomics. 2014;15(1):451.

52. Shojaei Saadi HA, Gagne D, Fournier E, Baldoceda Baldeon LM, Sirard MA, Robert C. Responses of bovine early embryos to S-adenosyl methionine supplementation in culture. Epigenomics. 2016;8(8):1039-60.

53. Salilew-Wondim D, Fournier E, Hoelker M, Saeed-Zidane M, Tholen E, Looft C, Neuhoff C, Besenfelder U, Havlicek V, Rings F, et al. Genomewide DNA methylation patterns of bovine blastocysts developed in vivo from embryos completed different stages of development in vitro. PLoS One. 2015;10(11):e0140467.

54. Desmet KL, Van Hoeck V, Gagne D, Fournier E, Thakur A, O'Doherty AM, Walsh CP, Sirard MA, Bols PE, Leroy JL: Exposure of bovine oocytes and embryos to elevated non-esterified fatty acid concentrations: integration of epigenetic and transcriptomic signatures in resultant blastocysts. BMC Genomics. 2016:17(1):1004.

55. Shojaei Saadi HA, Fournier E, Vigneault C, Blondin P, Bailey J, Robert C. Genome-wide analysis of sperm DNA methylation from monozygotic twin bulls. Reprod Fertil Dev. 2017;29(4):838-43.

56. Irizarry RA, Ladd-Acosta C, Wen B, Wu Z, Montano C, Onyango P, Cui H, Gabo K, Rongione M, Webster M, et al. The human colon cancer methylome shows similar hypo- and hypermethylation at conserved tissuespecific CpG island shores. Nat Genet. 2009;41(2):178-86.

57. Jones PA. Functions of DNA methylation: islands, start sites, gene bodies and beyond. Nat Rev Genet. 2012;13(7):484-92.

58. Yang X, Han H, De Carvalho DD, Lay FD, Jones PA, Liang G. Gene body methylation can alter gene expression and is a therapeutic target in cancer. Cancer Cell. 2014;26(4):577-90 
59. Irwin RE, Thakur A, KM ON, Walsh CP. 5-Hydroxymethylation marks a class of neuronal gene regulated by intragenic methylcytosine levels. Genomics. 2014;104(5):383-92.

60. Wu H, Coskun V, Tao J, Xie W, Ge W, Yoshikawa K, Li E, Zhang Y, Sun YE. Dnmt3a-dependent nonpromoter DNA methylation facilitates transcription of neurogenic genes. Science. 2010;329(5990):444-8.

61. O'Doherty AM, McGettigan PA. Epigenetic processes in the male germline. Reprod Fertil Dev. 2015;27(5):725-38.

62. Jones PA, Takai D. The role of DNA methylation in mammalian epigenetics. Science. 2001;293(5532):1068-70.

63. Klose RJ, Bird AP. Genomic DNA methylation: the mark and its mediators. Trends Biochem Sci. 2006;31(2):89-97.

64. Kulis M, Queiros AC, Beekman R, Martin-Subero Jl. Intragenic DNA methylation in transcriptional regulation, normal differentiation and cancer. Biochim Biophys Acta. 2013;1829(11):1161-74.

65. Neri F, Krepelova A, Incarnato D, Maldotti M, Parlato C, Galvagni F, Matarese F, Stunnenberg HG, Oliviero S. Dnmt3L antagonizes DNA methylation at bivalent promoters and favors DNA methylation at gene bodies in ESCS. Cell. 2013;155(1):121-34.

66. Ong CT, Corces VG. CTCF: an architectural protein bridging genome topology and function. Nat Rev Genet. 2014;15(4):234-46.

67. Filippova GN. Genetics and epigenetics of the multifunctional protein CTCF. Curr Top Dev Biol. 2008;80:337-60.

68. Bazer FW, Spencer TE, Johnson GA, Burghardt RC. Uterine receptivity to implantation of blastocysts in mammals. Front Biosci (Schol Ed). 2011;3:745-67.

69. Choux C, Carmignac V, Bruno C, Sagot P, Vaiman D, Fauque P. The placenta: phenotypic and epigenetic modifications induced by assisted reproductive technologies throughout pregnancy. Clin Epigenetics. 2015;7:87

70. Smith LC, Therrien J, Filion F, Bressan F, Meirelles FV. Epigenetic consequences of artificial reproductive technologies to the bovine imprinted genes SNRPN, H19/IGF2, and IGF2R. Front Genet. 2015;6:58.

71. O'Doherty AM, Magee DA, O'Shea LC, Forde N, Beltman ME, Mamo S, Fair T. DNA methylation dynamics at imprinted genes during bovine preimplantation embryo development. BMC Dev Biol. 2015;15:13.

72. O'Doherty AM, O'Gorman A, Al Naib A, Brennan L, Daly E, Duffy P, Fair T. Negative energy balance affects imprint stability in oocytes recovered from postpartum dairy cows. Genomics. 2014;

73. Roessler J, Ammerpohl O, Gutwein J, Hasemeier B, Anwar SL, Kreipe H, Lehmann U. Quantitative cross-validation and content analysis of the 450k DNA methylation array from Illumina, Inc. BMC research notes. 2012;5:210.

74. Melamed N, Choufani S, Wilkins-Haug LE, Koren G, Weksberg R. Comparison of genome-wide and gene-specific DNA methylation between ART and naturally conceived pregnancies. Epigenetics. 2015;10(6):474-83.

75. Vincent RN, Gooding LD, Louie K, Chan Wong E, Ma S. Altered DNA methylation and expression of PLAGL1 in cord blood from assisted reproductive technology pregnancies compared with natural conceptions. Fertil Steril. 2016;

76. Tee L, Lim DH, Dias RP, Baudement MO, Slater AA, Kirby G, Hancocks T, Stewart H, Hardy C, Macdonald F, et al. Epimutation profiling in BeckwithWiedemann syndrome: relationship with assisted reproductive technology. Clin Epigenetics. 2013:5(1):23

77. Bliek J, Verde G, Callaway J, Maas SM, De Crescenzo A, Sparago A, Cerrato F Russo S, Ferraiuolo S, Rinaldi MM, et al. Hypomethylation at multiple maternally methylated imprinted regions including PLAGL1 and GNAS loci in Beckwith-Wiedemann syndrome. Eur J Hum Genet. 2009;17(5):611-9.

78. Chen Z, Hagen DE, Ji T, Elsik CG, Rivera RM. Global misregulation of genes largely uncoupled to DNA methylome epimutations characterizes a congenital overgrowth syndrome. Sci Rep. 2017;7(1):12667.

79. Beltman ME, Lonergan P, Diskin MG, Roche JF, Crowe MA. Effect of progesterone supplementation in the first week post conception on embryo survival in beef heifers. Theriogenology. 2009;71(7):1173-9.

80. Chen Z, Robbins KM, Wells KD, Rivera RM. Large offspring syndrome: a bovine model for the human loss-of-imprinting overgrowth syndrome Beckwith-Wiedemann. Epigenetics. 2013;8(6):591-601.

81. Rizos D, Ward F, Duffy P, Boland MP, Lonergan P. Consequences of bovine oocyte maturation, fertilization or early embryo development in vitro versus in vivo: implications for blastocyst yield and blastocyst quality. Mol Reprod Dev. 2002;61(2):234-48.
82. Hyttel P, Callesen H, Greve T. Ultrastructural features of preovulatory oocyte maturation in superovulated cattle. J Reprod Fertil. 1986:76(2):645-56.

83. O'Doherty AM, O'Shea LC, Fair T. Bovine DNA methylation imprints are established in an oocyte size-specific manner, which are coordinated with the expression of the DNMT3 family proteins. Biol Reprod. 2012;86(3):67.

84. de Montera B, Fournier E, Shojaei Saadi HA, Gagne D, Laflamme I, Blondin P, Sirard MA, Robert C. Combined methylation mapping of $5 \mathrm{mC}$ and $5 \mathrm{hmC}$ during early embryonic stages in bovine. BMC Genomics. 2013;14:406.

85. Smyth GK, Michaud J, Scott HS. Use of within-array replicate spots for assessing differential expression in microarray experiments. Bioinformatics. 2005:21(9):2067-75.

86. McCarthy DJ, Smyth GK. Testing significance relative to a fold-change threshold is a TREAT. Bioinformatics. 2009;25(6):765-71.

87. Culhane AC, Thioulouse J, Perriere G, Higgins DG. MADE4: an R package for multivariate analysis of gene expression data. Bioinformatics. 2005:21(11): 2789-90.

88. O'Doherty AM, Rutledge CE, Sato S, Thakur A, Lees-Murdock DJ, Hata K, Walsh CP. DNA methylation plays an important role in promoter choice and protein production at the mouse Dnmt3L locus. Dev Biol. 2011;356(2):411-20

\section{Ready to submit your research? Choose BMC and benefit from:}

- fast, convenient online submission

- thorough peer review by experienced researchers in your field

- rapid publication on acceptance

- support for research data, including large and complex data types

- gold Open Access which fosters wider collaboration and increased citations

- maximum visibility for your research: over $100 \mathrm{M}$ website views per year

At BMC, research is always in progress.

Learn more biomedcentral.com/submissions 